\title{
The Role Played by Ngos in Preventing the Spread of Hiv/ Aids and Supporting People Living with Hiv/Aids in Tanzania: A Case of Dar Es Salaam Region
}

\author{
Tumpe Ndimbwa, Maria Emanuel and Emery Mushi \\ Centre for foreign Relations (CFR), P.O Box 2824 Dar es Salaam \\ Correspondence email: Mwakapalila@yahoo.com
}

DOI: 10.6007/IJARBSS/v3-i11/377 URL: http://dx.doi.org/10.6007/IJARBSS/v3-i11/377

\begin{abstract}
HIV has blazed throughout sub-Saharan Africa, particularly Southern Africa, leaving almost no community unaffected by its devastating effects. Despite successful interventions in some countries and communities to combat the virus, it has continued to wreak its havoc at an alarming rate. This paper aimed at investigating the role played by NGOs in preventing the pandemic as well as supporting the infected people with HIV/AIDS. The study findings reveled that, NGOs in Tanzania play a big role in preventing the spread of the disease. However, In order for these organizations to be effective and efficiency more efforts from the government are needed to support these Non government organizations.
\end{abstract}

Key words: HIV/AIDS, NGOs

Introduction

The world has rapidly become more vulnerable to the eruption and the global spread of new infectious diseases. Nothing symbolizes this new global vulnerability more than AIDS pandemic. Twenty three years after the first clinical evidence of Acquired Immunodeficiency Syndrome popularly known as AIDS was reported in the USA, it has become "the most devastating pandemic humankind ever witnessed" (Awake, 2002). According to UNAIDS/WHO (2006), an estimated 39.5 million people were living with HIV/AIDS by 2006 . There were 4.3 million new infections by 2006 with 2.8 million (65\%) of these occurring in Sub-Saharan Africa. There is also indication that in Eastern Europe and Central Asia the infection rates have risen by more than 50\% since 2004. In the year 2006, the epidemic claimed the lives of an estimated 2.9 million people in Africa.An estimated 1.4 million (1.3 million - 1.6 million) adults and children were living with HIV in the United Republic of Tanzania at the end of 2005, making it one of the most affected countries in the world. According to projections, the number of new HIV infections in rural areas (where about the three quarters of the country's population live) could be twice as high as in urban areas by 2010 (UNAIDS/WHO, 2006:18). To combat the spread of this disease, the UN and the developed governments of the world have been playing an important role. For example, the US government has been in the forefront in the crusade against HIV/AIDS in Africa especially in this new millennium. As noted by the World Watch Institute, the HIV epidemic raging across Sub-Saharan Africa is a tragedy of epic proportion. In 
the same manner. Koffi Annan (2000) while talking on the impact of HIV and AIDS in the achievement of Millennium Development goals in Africa reported that, the disease affects region's development and demographic future, reduce life expectancy and raise mortality rate and lowering fertility as well as leaving millions of orphans in its wake.

Acquired Immunodeficiency Syndrome (AIDS) is a world wide problem which affects every face of human life. It is caused by a virus called human immunodeficiency virus (HIV). So far neither vaccine nor cure for the disease has been discovered. This means that once people infected by the virus eventually they die. On average, an infected person dies within two to ten years. HIV/AIDS is among the leading cross-cutting challenges to national development in Tanzania. The first three AIDS cases were reported in Tanzania in 1983. Since then, HIV/AIDS has been spreading throughout Tanzania affecting urban and rural areas (Idasa, 2008). Institutionalized interventions addressing HIV and AIDS in Tanzania started in 1985, with the National AIDS Control Program (NASP) being established in the same year under the Ministry of Health. Therefore, HIV/AIDS was declared a national disaster in 1999. Since then the number of cases has continued to rise at a very fast rate (Idasa, 2008). Again, according to NASP Report (2006) and TACAIDS (2005) it was estimated that the HIV prevalence among adults was approximately $7 \%$ in a population of 33 million by 2003 whereby approximately 1.8 million people are living with HIV and AIDS on the mainland. About $60 \%$ of bed occupancy is due to HIV and AIDS related illnesses in hospitals. Almost everywhere AIDS is taking a terrible toll resulting in one out of ten children being orphaned and looked after by grandparents if they are still alive. However, sometimes the eldest child has to become the bread winner sacrificing his or her own future to bring up brothers and sisters. As orphans, these children undoubtedly have a high risk of malnutrition, suffer from the stress of seeing their parents die, become surrogate parents to their younger siblings or coerced into early sexual activities and probably never see the inside of a school(ibid).

\subsection{Concepts and Definitions}

\subsubsection{NGOs.}

A non-governmental organization (NGO) is any non-profit, voluntary citizen's group which is organized on a local, national or international level. Task oriented and driven by people with a common interest, NGO perform a variety of service and humanitarian functions, bring citizen concerns to Governments, advocate and monitor policies and encourage political participation through provision of information. Some are organized around specific issues such as health, environment or human rights. For the sake of this study, NGOs discussed here are those particularly dealing with HIV and AIDS. These are non governmental organizations mostly established by people living with HIV/AIDS, (PLWHA)

\subsubsection{WAMATA}

This is the oldest NGOs in Tanzania dealing with HIV/AIDS. It was formed in 1989 by a group of people living with HIV/AIDS. It has chartered the road map for most of the HIV/AIDS service NGOs and community based organizations and brought HIV/AIDS problem to the attention of government. 


\subsubsection{PASADA}

Is a social service agency operating under the Roman Catholic Archdiocese of Dar es Salaam. It was started in August 1994 when the Archbishop of Dar es Salaam mandated Rev. Fr. Georges Loire to initiate a pastoral service to respond to the needs of people suffering from HIV/AIDS.

\subsection{Empirical review}

AIDS is affecting the entire population in one way or another. Political leaders, mass media, religious institutions, government and non government organizations have a wider ground to play._Due to the high spread of the disease, there have been various efforts and plans to combat the pandemic. For example, in 2001, an Act of Parliament established the Tanzanian Commission for AIDS to lead the multi-sectoral National Response under the Prime Minister's Office. The government has played a crucial role by establishing TACAIDS. Also in November 2002, the National Policy on HIV and AIDS was developed and approved by Parliament. Again in January 2003, the National Multi-Sectoral Strategic Framework for HIV/AIDS was approved by the government with representatives from government, civil society, faith-based organizations, development partners and the private sectors were consulted in the development of the document. (NMSF 2003-2007) Moreover, in November 2005, the former president of the United Republic of Tanzania Excellency Benjamin Mkapa, said that, the estimation of the spread is that of $7 \%$ of the entire population is already infected by the deadly virus, despite the allocated budget of Tsh. 20 billion for 2005/2006 financial year to fight the disease; the NGOs have a social and crucial role to play in protecting or alerting the $93 \%$ of uninfected population and encouraging 7\% already infected to live with hope, (TACAIDS NO. 002, JUNE 2006 p. 17). Of late more than ever before, the above mentioned categories have been working tirelessly to educate people on the consequences of the disease. Despite these efforts; so far no cure has been discovered for the disease, but increasingly, preventive and treatment measures are developed. Condoms and antiretroviral drugs have most often been used as prevention and treatment respectively for the pandemic. Again, this has come under severe criticism. The pharmaceutical companies where these items come from are based in the West and the drugs are beyond the reach of those in need because the prices at which they are sold are exorbitant even at government subsidized rates.

However, Nyoni (2005) argues that, the main task facing African countries is the lacking of vigorous publicity campaigns on the dangers of HIV and AIDS. In spite of the commendable efforts undertaken by the government of Tanzania to prevent the spread of HIV and AIDS, there is a gap in preventing the spread of the pandemic. This gap is filled by the NGOs which are dealing with the disease. The approach of "do small but better" program intervention in the provision of services has produced good results to people who are living with HIV/AIDS. A study done by Jamil (1998) revealed that,NGOs stand advantageous over government in dealing with social problems of HIV/AIDS as they are more democratic and result oriented compared to government bureaucracies which are process oriented. Due to its known for flexibility, NGOs are easily to adapt changes wherever required so as to meet the needs of its clients in preventing the spread of HIV and AIDS. Tanzania is a country fluid with NGOs, in recent times; the number of those NGOs interested in HIV/AIDS has tremendously grown. The Tanzania AIDS Commission (TACAIDS) had registered more than three hundred NGOs and Community Based 
Organizations which are working in the field of AIDS (TACAIDS, 2006). The growth of the HIV/AIDS organizations can be explained by several factors. First, Civil Society gained prominence in the mid 1990's with the realization that HIV/AIDS was no longer just a medical (health) problem but also a social problem. The care and support regained by those infected with HIV/AIDS led to the realization that HIV/AIDS has multiple faces with the sociological face regaining on immediate attention as was medical or biological (Small, 1997). With increased rate of infections and little state response in terms of getting more involve and devising solutions to problems inflicted by HIV/AIDS, NGOs developed to fill the gap. Stimulated by social exclusion, increased spread, neglected public responsibility and threatened employment status, HIV/AIDS organizations were born in late 1980s by a group of people who faced such challenge of exclusion and member livelihood. Today their initiative has gone beyond looking at themselves (PLWHAS), to teach the whole world about the need to come together to fight the dangerous disease. In Tanzania and elsewhere in Africa, for example Uganda and South Africa, HIV/AIDS NGOs developed as a result of a need to form self help programs to provide for the HIV/AIDS affected persons. For example, The WAMATA and PASADA developed to support the socially excluded, provide care and counseling services and community outreach programs. They are two of the biggest NGOs providing HIV/AIDS related services in Tanzania. Secondly, with the failing states responsibility towards HIV/AIDS, NGOs gained prominence and recognition by the International Donor Community which sought to channel development aid through them. The World Bank's multi-country AIDS program for Africa explicitly aims to use non-governmental organizations (NGOs) as implementing partner for approximately $50 \%$ for the funding provided (UNAIDS, 2002). In his paper Mohga, (2002) recommended that, NGOs should contribute to the global decision making process on AIDS. He also recommended that, the country coordination Mechanisms should give a strong voice to NGOs in decision making, programming, implementation, monitoring and evaluation of projects of various kinds carried out in the countries. The recent support from World Bank for community HIV/AIDS initiative requires that money be channeled through NGOs and Community Based Organization (CBO) involved in HIV/AIDS related activities; participatory approaches involving people living with HIV/AIDS, community based information, education and communication (IEC) initiatives, poor orphaned children's education etc (PASADA records). This requirement has led to further growth of HIV/AIDS organizations. Thirdly, as market forces make the state to relinquish the few responsibilities it held in public spending, more attention is being put on the role of civil society. It is important to note that the days when health depended on public spending have come to an end. Today, most countries, including the traditional welfare countries are looking at the complementary role of the private sector in providing health care. In developing countries, with state pull-back and the market taking the lead in providing health care, the poor are left out with barely any services. Given this situation, in developing countries, under the market system, the poor and other disadvantaged groups such as PLWHA will find difficult to survive individually.

Threatened by the disease, most of the families in Tanzania including poverty stricken rural households have used a big portion of their incomes and resources in responding to the challenges of HIV/AIDS. The fact that medical treatment in Tanzania is not fully provided worsens the situation. The government endeavors are not adequate to carter for Home Based Care services ( $\mathrm{HBC})$, Voluntary Counseling and Testing (VCT), $\mathrm{MCH}$, Orphans and Vulnerable 
Children (OVC), care to the people affected and infected by HIV and AIDS. This is reflected in the national budget allocation for Ministry of Health and Social Welfare. Therefore, NGOs like WAMATA and PASADA have come up to fill this gap and provide services for the poor people. These NGOs have outpatient clinics which provide medical services to the sick promote access to voluntary counseling and testing; and care services. For example, from 2001 to 2006 a total number of 62,977 individuals turned at PASADA clinic and accessed the VCT services (PASADA, 2006:16). Mercer, et al. (1991) suggested that, as the epidemic of HIV/ AIDS continues to expand to all corners of the globe, it is clear that every sector of society must respond. They added that, AIDS is no longer a concern just of health authorities and government. The potential impact of AIDS makes it a challenge in economic, political, social and religious spheres as well. Among organisations responding to the crisis, non-governmental organisations (NGOs) are emerging as a powerful force in the effort to contain the epidemic. Diverse groups at risk of HIV infection have been reached by NGOs in a wide variety of innovative programmes.

\section{MATERIALS AND METHODS}

\subsection{Research Design and Unity of Analysis}

The study was carried out in Dare s Salaam region which is located in the East Coast of Tanzania. It is bordered by Indian Ocean to the East and on all other sides by coastal region. The selection of the area was due to two reasons; first, Dar es Salaam has a big population over 4 Million people of different characters. A research design is a detailed blue print used to guide a research study towards its objectives (Aaker et al 1998:71). The process of designing a research study involves many interrelated decisions. This study of the role of Non governmental organization in preventing the spread of HIV/AIDS in Tanzania was qualitative and quantitative in nature and applied a case study design. The case study design was employed because it allows a deep study of the social unit over a range of variables while maintaining its unitary nature.

The collected data from the field was edited to remove errors, incompleteness and the inconsistency and then was verified, compiled and coded prior to analysis which was done using the Statistical package for social scientists (SPSSx) computer programmes. Data from the structured questions were analyzed quantitatively and the results are presented in tables and figures in frequencies and percentages. While the qualitative data from the open-ended questions and focus group discussions were analyzed through classification and reorganization of different sub themes, as well as identification of similar and dissimilar aspects of the study in the interviews. Quantitative and qualitative results are reported concurrently in such a way that the qualitative results are used to elaborate and validate the quantitative findings. Tables and percentages were also used to present the findings of this study.

\section{RESULTS AND DISCUSSION}

\subsection{Response Rate}

The researchers distributed about 72 questionnaires to the respondents, out of these $26(36 \%)$ were given to WAMATA and $46(64 \%)$ were distributed to PASADA. The number of respondents from each category is shown on Figure 1; 
Figure 1: Respondents response rate ( $N=72)$

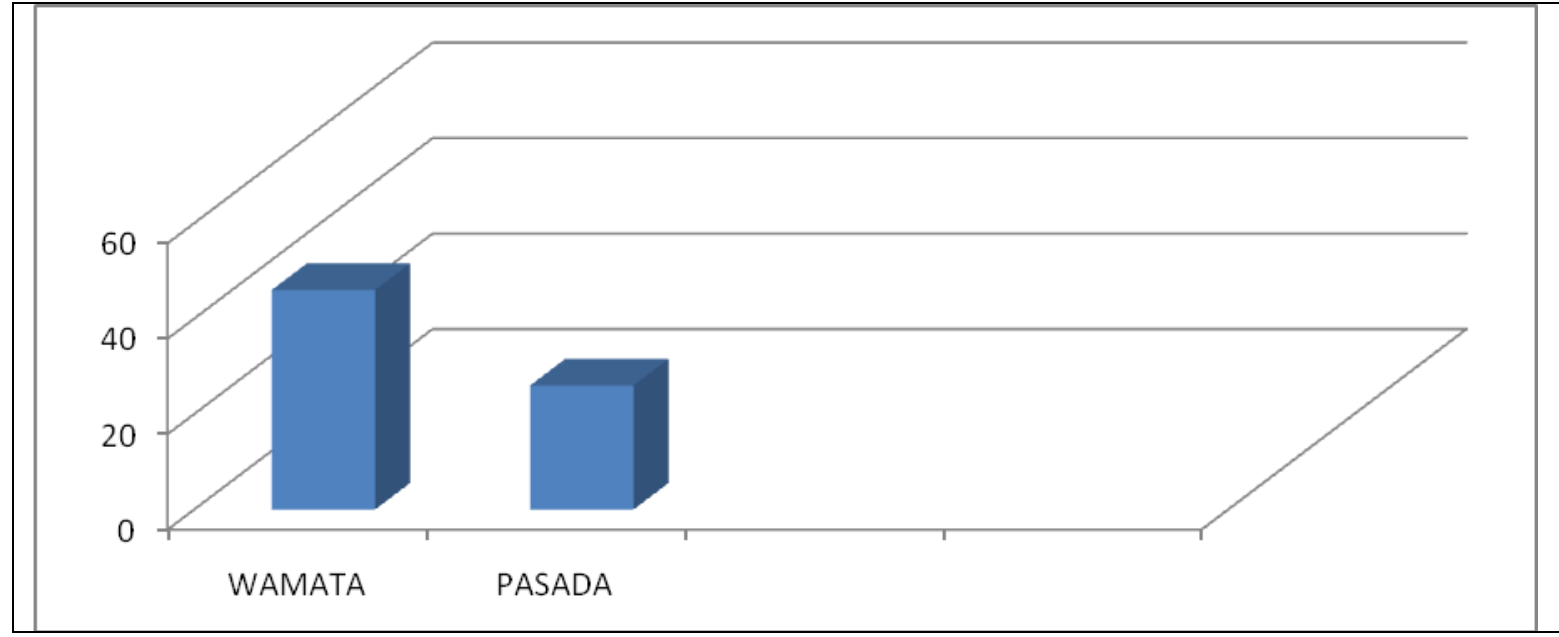

Source: Researcher's Field Data Analysis (2013)

The study findings in Figure 1, showed that, the response rate was high whereby all respondents $(100 \%)$ returned their questionnaires. The major reason for the high response rate is the follow up done by the researcher. The high response rate also suggests that the sampling techniques used were appropriate and the sample size was manageable. The main categories of respondents were people living with HIV and AIDS and clinical staffs of NGOs providers

\subsection{Causes of HIV and AIDS in the study area}

In this area the researcher asked the 47 respondents who were living with HIV and AIDS to mention some of the factors that contribute to the spread of HIV and AIDS in the study area. The followings were the results; $27(57 \%)$ of the respondents mentioned sexual transmitted disease to be the main cause, followed by 12 repondents $(26 \%)$ who said poverty while 8 respondents (17\%) mentioned low status of women within the society to the source of HIV and AIDS. See the findings in Figure 2;

Figure 2: Causes of HIV and AIDS ( $N=47)$

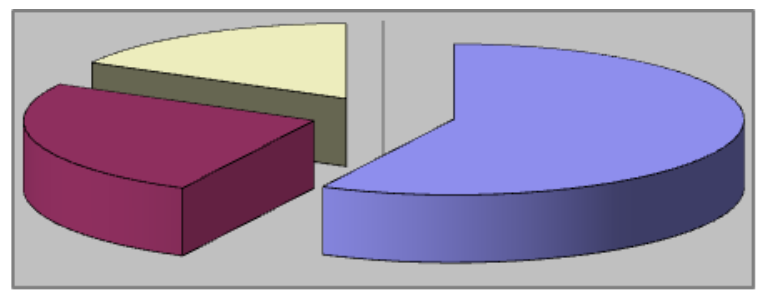

$\begin{aligned} & \square \text { Sexual transmitted } \\ & \text { disease } \\ & \square \text { Poverty } \\ & \square \text { Low status of women }\end{aligned}$

Source: Researcher's Field Data Analysis (2013) 
The study findings in Figure 2 indicated that, the major cause of HIV and AIDS is associated with sexual transmitted diseases. These findings concur with those found by Devincenzi (1994) and Royce et al, (1997) that, persons living with STD have three to five fold increases in risk of being infected with HIV than those who are not having sexually transmitted diseases. However, the study done by Royce et al (1997) revealed that treatment of STDs reduces the risk of HIV transmission by $40 \%$ and that, STDs are not the only way an individual could transmit the infection to another person because there are other ways of transmission such as anal sexual intercourse and drug abuse which are among key factors contributing to the escalating infection rates, and further spread of the disease. Moreover, poverty was mention as the second factor whereby about (26\%) of the respondents listed it as a cause of HIV and AIDS in the study area whereby over (50\%) of Tanzanians live below the poverty line and females are worse than males (CHAL, 2001) These findings were also supported by UNAIDS (2001) report that, poverty have forced young women into commercial sex in exchange for material benefits due to unemployment to many school leavers which results in having nothing better to do with their time.

\subsection{Roles played by NGOs (PASADA and WAMATA) in providing services to the people who} live with HIV/AIDS IN Tanzania

In this question, respondents were asked to mention some of the services that are provided by PASADA and WAMATA organizations. The study findings are presented in Table 1;

Table 1: Services provided by PASADA and WAMATA ( $N=47)$

\begin{tabular}{|l|l|}
\hline \multicolumn{1}{|c|}{ PASADA } & \multicolumn{1}{|c|}{ WAMATA } \\
\hline Spiritual counseling & counseling \\
\hline Orphan support & Training \\
\hline Social assistance & Awareness campaign \\
\hline Medical services & Supporting Orphan \\
\hline Soluntary counseling and testing & Medical services \\
\hline Home based care & Material support \\
\hline Community education & HIV education \\
\hline Supporting elders & Prevention of mother to child \\
\hline
\end{tabular}

Source: WAMATA\&PASADA (2013).

The findings above were supported by the studies done by Mercer et al. (1991) and NORAD (1991) who found that, NGOs are willing to involve and support those individuals who 
are poor and marginalised such as such as prostitutes or intravenous drug users, HIV victims and those who are outside the mainstream society. However, when the researcher asked people who live with HIV and AIDS to name some of the services which they receive from the above organizations, added that, some of the mentioned services above were not provided for instance prevention of mother to child transmission and supporting elders. However (90\%) of the PLWHA reported to be satisfied with the services provided with PASADA and WAMATA compared to public hospitals service.

\subsection{Services Provided by WAMATA}

Percentage distribution of respondents ranking different services provided by NGO'S according to their importance .The findings in Table 2, showed that, WAMATA were providing the following services to the people who were living with HIV/AIDS in Dar es Salaam.

Table 2: Services Provided by WAMATA

\begin{tabular}{|l|l|l|l|l|}
\hline Categories & Services provided & $\begin{array}{l}\text { Number of } \\
\text { respondents }\end{array}$ & Percentage & Rank \\
\hline 1 & $\begin{array}{l}\text { Medical Care and } \\
\text { Treatment }\end{array}$ & 18 & $90 \%$ & 1 \\
\hline 2 & $\begin{array}{l}\text { Voluntary Counseling } \\
\text { and Testing }\end{array}$ & 17 & $85 \%$ & 2 \\
\hline 3 & $\begin{array}{l}\text { Community } \\
\text { Education }\end{array}$ & 17 & $85 \%$ & 2 \\
\hline 4 & $\begin{array}{l}\text { Home-Based care } \\
5\end{array}$ & 16 & $80 \%$ & 4 \\
\hline
\end{tabular}

Source: Researcher's Field Data Analysis (2013)

On the other hand, respondents were asked to mention the services that were provided by Pasada to the people living with HIV/AIDS. Respondents were required to give multiple answers their results are presented in Table 4; 
Table 4: Services provided by PASADA

\begin{tabular}{|l|l|c|c|l|}
\hline Categories & Services provided & $\begin{array}{c}\text { Number of } \\
\text { respondent } \\
\text { s }\end{array}$ & Percentage & Rank \\
\hline 1 & Medical Care and Treatment & 26 & $96.2 \% \%$ & 1 \\
\hline 2 & $\begin{array}{l}\text { Voluntary Counseling and } \\
\text { Testing }\end{array}$ & 25 & $92.2 \%$ & 2 \\
\hline 3 & $\begin{array}{l}\text { Orphans and Vulnerable } \\
\text { Children }\end{array}$ & 24 & $88.8 \%$ & 3 \\
\hline 4 & Home-Based Care & 23 & $85 \%$ & 4 \\
\hline 5 & Community Education & 22 & $81.3 \%$ & 5 \\
\hline
\end{tabular}

Source: Researcher's Field Data Analysis (2013)

Basing on the findings above, more than $90 \%$ of the services provided by these organizations were medical care and treatment, simply because these services were free provided to people who live with HIV/AIDS especially ARVs which improve their quality of life through diagnosis and treatment of opportunistic infections. To prove these one of the respondent who use ARVs testified that, "I started using ARV's in 2005. My health condition was improved as I continued to take medicine. I come here (NGO-WAMATA) to collect medicines and check my health whenever I feel something wrong in my body. I get free medical services. Now I can take care of my life, as I go on in my daily life. I don't have a wife, she died 2004, and now I am living with my children".

From the above testimony, it was found that most of the PLWHA did not have ability to meet the cost of expensive treatment in private health facilities. This was due to the fact that those people were very poor due to prolonged illness which paralyzed their economic liability; hence they were forced to look for free medical services. To support this one of the officials from PASADA reported that, the availability of free medical services greatly contributed to reducing mortality and morbidity of PLWHA. On average 3,000 clients access medical assistance every month (PASADA, 2010). Moreover, these organizations provide education that, aimed at reduction of HIV and AIDS related stigma and discrimination. The creation of awareness on these issues is undertaken in various clubs formed by different organizations, such as drama clubs under WAMATA YOUTH and PASADA and DACHEP (Dar es Salaam Archiodiocese Community Health Education Program. For example, counseling and community based education was mentioned to be the important services due to the fact that, community tend to discriminate HIV victims hence, education is needed to create consciousness among the community. Regarding Integrated TB/HIV and AIDS service, it was found that these NGO's try to make early TB diagnosis and to start treatment in people who are HIV positive. They initiate diagnosis according to the National Guidelines. The clients not only receive medication, but also 
those who are HIV positive and have been cured of TB are trained on how to go into the community, share their experiences, teach community members and combat fear of stigma associated with the disease.

The findings revealed that, PASADA was also implementing a program of mother to child transmission (PMTCT) .This programme started in the satellite dispensaries in June, 2002 and by 2006, there were 12 dispensaries all having maternity units or MCH clinics. The aim of the program was to contribute to the reduction of HIV incidence among infants born to HIV positive mothers. Education was provided to women on testing HIV+ as to the necessity of delivering in specific maternity units whereby Nevirapine was administered to the mother and her new born child. See the findings in Table 5;

Table 5: PMTCT Services from 2004 and 2005

Evidence indicated by the following statistics showing the number of women receiving

\begin{tabular}{|l|l|}
\hline Category & Number \\
\hline $\begin{array}{l}\text { Pregnant women attended the antenatal } \\
\text { clinic }\end{array}$ & 22,424 \\
\hline $\begin{array}{l}\text { Pregnant women attended the antenatal } \\
\text { clinics agreed to HIV counseling and } \\
\text { testing. }\end{array}$ & $6912(30.8 \%)$ \\
\hline Found with HIV positive & 705 \\
\hline Able to follow Nevirapine & 126 only (17.9\%) \\
\hline
\end{tabular}

Source: PASADA (2009)

From the findings above it was clear that, many women tend to attend clinic during their pregnant, but most of them are not ready to be tested for HIV/AIDS. The few who were tested and found to be HIV positive also were not ready to follow Nevirapine programme this might be due to fear of the consequences of receiving an HIV positive test result. Also women fear to tell their partners as they know that the results may be physical violence, abandonment and hence sole responsibility for the burden of children may be the reason behind the low response rate.

\subsection{The Extent of Preventing the Spread of HIV and AIDS PASADA and WAMATA}

The researchers asked the representative from these Pasada to explain their achievement in preventing the spread of HIV and AIDS in Kinondoni and Temeke Districts. The study findings showed that, there was an increase of patient registered and attended by these organizations from 2005. for instance, Respondents' who were living with HIV/AIDS testify for themselves that, HIV/AIDS rate is increasing in Tanzania and is a serious problem which need special attention. The disease has spread widely. There is hardly any part of the country unaffected. Although the national prevalence rate has continued to decline, there are still 
indications that HIV/AIDS is still spreading. Both Tanzania AIDS Commission (TACAIDS) and (NGOs) like WAMATA and PASADA continue to register increasing numbers of new client's country wide. See the findings in Figure 3;

Figure 3: An Increase of Patient with HIV/AIDS at PASADA

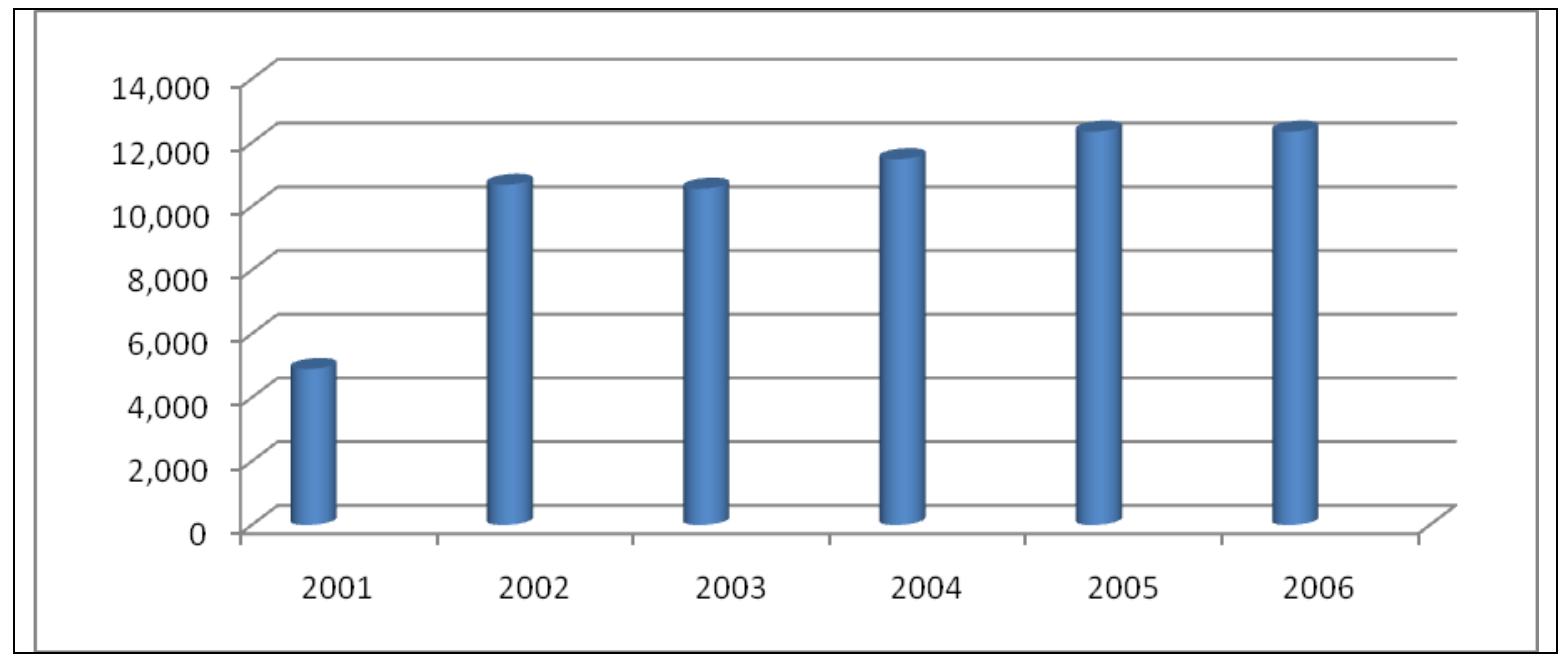

Source: Pasada, Best Practices (2006)

\section{Challenges facing PASADA and WAMATA in the prevention of HIV and AIDS}

In this question the researchers asked the respondents from these organizations to name some of their problems in dealing with HIV/AIDS in the study area. The study findings were as follows; 10respondents (40\%) mentioned age and gender to be the challenge while 12respondents (48\%) said traditional taboos. About 14 respondents (56\%) mention stigma and discrimination among the community. Accordingly, about 11respondents (44\%) said reluctance of parents to disclose their HIV status to children, while 5respondents (20\%) name religious stand and only $4(16 \%)$ of respondents listed ignorance among community members. These findings are presented in Table 6 ;

Table 6: Problems encountered by NGOs staff

\begin{tabular}{|l|l|l|l|l|}
\hline S/No. & $\begin{array}{l}\text { Problems encountered in dealing with } \\
\text { prevention of HIV/AIDS }\end{array}$ & $\begin{array}{l}\text { No. } \\
\text { Respondents }\end{array}$ & percentage & Rank \\
\hline 1 & Age and gender & 10 & $40 \%$ & 4 \\
\hline 2 & Traditional Taboos & 12 & $48 \%$ & 2 \\
\hline 3 & Stigma and discrimination & 14 & $56 \%$ & 1 \\
\hline 4 & Religious stand & 5 & $20 \%$ & 5 \\
\hline 5 & $\begin{array}{l}\text { Reluctance of parents to disclose their } \\
\text { HIV status to children }\end{array}$ & 11 & $44 \%$ & 3 \\
\hline
\end{tabular}




\begin{tabular}{|l|l|l|l|l|l|}
\hline 6 & $\begin{array}{l}\text { Ignorance among community } \\
\text { members }\end{array}$ & 4 & $16 \%$ & 6 \\
\hline
\end{tabular}

Source: Field Data (2013 Note: not added to $100 \%$ due to multiple answers

The findings in table 6 above shows that the main problem encountered by the clinical staff in provision of services to PLWHA were stigma and discrimination whereby about $56 \%$ mention this to be their main problem, followed by traditional taboos (48\%) and reluctance of parents to disclose their HIV status to children by (44\%), although age and gender were mention to the problem. These findings concur with those found by UNAIDS (2002 that, individuals suffering from HIV/ AIDS are stigmatised and ostracised by their loved ones, their family and their communities, and discriminated against individually as well as institutionally HIV/ AIDS-related stigma and discrimination build upon, and reinforces, existing prejudices. They play into and strengthen existing social inequalities, especially those of gender, sexuality and race. HIV/ AIDS victims are denied health services and education, or may lose employment on the grounds of their HIV status.

\subsection{Conclusion}

The study concludes that, in spite of the increasing challenges of HIV/AIDS which are developmental threat, NGOs are important agents for limiting the impacts of HIV/AIDS which help in provision of free services lead to sustain livelihoods for people living with HIV/AIDS. The extent to which NGOs have contributed in preventing the spread of HIV/AIDS in Tanzania is encouraging. For example more than $90 \%$ of respondents reported to be recipients of medical services from the NGOs. Many PLWHA who are registered in these organizations testified that if it were not these NGOs they would have died long time ago. Clients confessed that these NGOs have given them new hope of life. Their health status has been improved, prolonged life and some of them have returned to productive activities. However, the challenges of HIV/AIDS are many and cannot be addressed alone by technical and formal institutions. The situation needed a more social approach by which NGOs by creating solidarities and identities among people affected by HIV/AIDS have managed to overcome social stigma, discrimination, spread and cure of the disease.

\subsection{Recommendations}

Based on the research findings, the study recommended that, more effort is needed for success in preventing the spread of HIV/AIDS in Tanzania. Both public and NGOs should find convenient methods to work together so as to minimize further infections for those not yet infected. Schools authorities should by law required to hold HIV/AIDS talks with school children every fortnight and include HIV/AIDS on all health educational talks every week. Finally, the government should allocate more funds to those NGOs dealing with HIV/AIDS and work with them more closely in order to support and care to persons with AIDS. 


\section{REFERENCES}

Abdool-Karim et al (1992), Prevalence of HIV infection in rural South Africa. AIDS: Expertise meeting of AIDS report in Switzerland.

Benjamen, N (2003) "The US and UN Response to the AIDS Crisis in Africa" Frank Columbus (ed), Politics and Economics of Africa, Vol. 4, New York: NOVA Science Publishers Inc., p. 4.

Best, J. O. and Khan, J. (1998): Research in Education $8^{\text {th }}$ Ed. Needhan Neights, A. Allyn and Bacon.

Bourke (2006), Christian Health Association of Lesotho (CHAL). AIDS strategic plan 2001: 15-20

Coutinho, A. (2003) Civil Society, HIV/AIDS and Access to care. $13^{\text {th }}$ International Conference on AIDS and STIs in Africa, Nairobi.

Devincenzi, I. Longitudinal study of human immunodeficiency virus transmission by heterosexual partners. New Engl J med 1994; 331: 341-346

Garbus, L \& Marseille (2003). HIV/AIDS in Uganda. Country AIDS Policy Analysis Project. California, University of California

Holland et al (1991), Resistance, Empowerment: Young women and the negotiation of safer sex. London. London. The Tufnell Press (WRAP) paper No. 6, 1991.

Holland et al (1992), Risk power and the possibility of pleasure: Young women and safer sex. In: AIDS Care 4;3, 1992.

Jonsson, C. and Söderholm (1995) "IGO - NGO Relations and HIV/AIDS: Innovation or Stalemate" Third World Quarterly Vol. 16 (3): 459-476.

Kellinger, F. N. (1983): Foundation of Behaviors research. New York, Hort Renehart and Winston Inc.

Kemenade, V. (2002). Social Capital as Health Determinant: How is it measured, Health Canada, Working Paper 02-08, March 2003.

Khan, J, Roy B. (1997) Role of NGOs in HIV/AIDS/STD prevention \& control in Bangladesh: a case study on targeted interventions with trucker's community. Ann. Conf. Australas Soc HIV Med. 9: 157 (poster no. P78).

Koffi Annan (2000), UN Secretary General "Impact of AIDS on Peace and Security in Africa, $4086^{\text {th }}$ meeting, Press Release, Sc/6781, 10 ${ }^{\text {th }}$ January, 2000.

Kothari, G. R. (1990), Research Methodology: Methods and Techniques $2^{\text {nd }}$ Ed. Indian, US John for Wiles Eastern Limited.

Lobb, C. (2002). Museveni In US to seek Investment, attack protectionism; www.AllAfrica.com. 2003

Mohga, K., Smith (2002), World Health: False Hope or New Start? The Global Fund to Fight HIV/AIDS, TB and Malaria, Oxfam Policy Papers, http://www.oxfam.org/eng/policypape.htm.2003

Ministry of Health \& Social Welfare (MOHSW). STD/HIV/AIDS Prevention and Control Program, 1999.

Monico, M., et al (2001) Uganda: HIV and AIDS-related Discrimination, Stigmatization and 
denial. Geneva, UNAIDS.

Moore, Jim. The Origin of HIV and the First Cases of AIDS. American Scientist, November December, 2004

Muriisa, R. (2001) NGOs and Rural Development in Uganda. Public Administration and Organization Theory. Bergen University of Bergen.

NACP report in Care and Treatment Partners meeting on $18^{\text {th }}$ September, 2006.

National Aids Control Programme (NACP) (2006) Surveillance of HIV and Syphilis Infections among antenatal Clinic Attendee 2005/06, Dar es Salaam Tanzania.

National Aids Control Programme (2006), Historical background of HIV/AIDS epidemic in Tanzania, http://www.nacptz.org/publications/NACP\%20 retrieved on 31 ${ }^{\text {st }}$ March, 2010.

National Aids Control Programme (NACP) (2006), Surveillance of HIV and Syphilis Infections among Antenatal Clinic Attendee 2005/06, Dar es Salaam, Tanzania

National Multi-Sectoral Strategic Framework on HIV/AIDS (2003-2007)

Oguntibeju OO, Veldman D \& Van Schalkwyk F(2002), Biological, social, and environmental factors affecting sexual transmission of HIV infection. Medical Technology

PASADA, 2006: Best Practice, Building on Hope

Paxon WA, Marin SR, Tse D. relative Resistance to HIV-1 infection of CD4+ lymphocytes from persons who remain uninfected despite multiple sexual exposures. Nature Medicine .

Piot, P. et al (2007) Squaring the Circle: AIDS, Poverty and Human Development

Royce RA,(1997), Sexual transmission of HIV. New England

Small, (1997). Suffering in Silence? Public Visibility, Private Secrets and the social Construction of AIDS. AIDS: Activism and Alliances. P. Aggleton, P. Davies and G. Hart. London, Taylor and Francis.

Smith KJ, Skelton HG, Wagner KF(1995), Pathogenesis of HIV-1 Disease. Int J Dermatol 34: 308-318

Stake, R. E. (1994): Case Study N. K. Denzin and Y. S. Linedon (Eds) Handbook for X qualification research, Thousands Oaks, C. A. Sag.

Stephen Lewis (2002), UN Special Envoy for HIV/AIDS in Africa, made this assertion during the World Conference on HIV/AIDS held in Durban, South Africa.

TACAIDS (2006) Tanzania HIV/AIDS Indicator Survey. TACAIDS(2006) Issue No. 002, Tanzania

The WAMATA, Strategic Plan For the Period 2005-2008, Dar es Salaam, Tanzania.

UNAIDS (2002). AIDS Epidemic Updates. Geneva, UNAIDS.

UNAIDS (2010) http://www.unaids.org/en/CountryResponses/Countries/india.asp

United Nations Program on HIV/AIDS. Global HIV/AIDS Epidemics. UNAIDS Fact Sheet, 2001.

Veeramatha, C.S. Role of NGOs in the Prevention of HIV/ AIDS in Karnataka, available online at http://www.isec.ac.in/prc-abs17.pdf 